\title{
First record of Papilio demoleus Linnaeus, 1758 (Lepidoptera: Papilionidae) from Aleppo, West Syrian Levant
}

\section{Первое указание Papilio demoleus Linnaeus, 1758 (Lepidoptera:

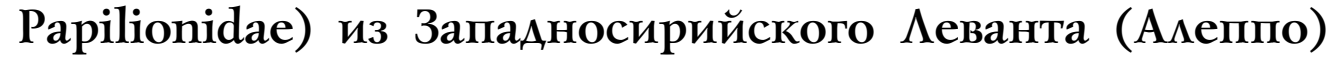

\author{
N.H. Zarikian \\ Н.А. Зарикян
}

Scientific Center of Zoology and Hydroecology, National Academy of Sciences of Armenia, P. Sevak Str. 7, Yerevan 0014 Armenia. E-mail: noushigz@hotmail.com.

Научный центр зоологии и гидроэкологии НАН РА, ул. П. Севака 7, Ереван 0014 Армения.

Key words: Aleppo, climate change, Lepidoptera, Papilio demoleus, Syria.

Ключевые слова: Алеппо, изменения климата, Lepidoptera, Papilio demoleus, Сирия.

Abstract. The Lime Swallowtail Papilio demoleus Linnaeus, 1758 (Lepidoptera: Papilionidae) is an ecological indicator in Syria and the most studied butterfly species since it is widespread and dangerous to agriculture. Since its first appearance in Palmyra in 2003-2006, this is curiously the first time it has been recorded in Aleppo; its appearance is probably associated with abandoned agricultural areas due to the war or with climate change.

Резюме. Парусник Papilio demoleus Linnaeus, 1758 (Lepidoptera: Papilionidae) является одним из экологических индикаторов в Сирии и наиболее изученным видом бабочек, частично вследствие широкого распространения и вреда для сельского хозяйства. После первого указания Д. Беньямином и др. из Пальмиры в 2003-2006 г., вид впервые указывается из Алеппо. Появление его здесь может быть связано с образованием заброшенных вследствие военных действий сельскохозяйственных земель или с изменениями климата.

\section{Introduction}

Lime Swallowtail Papilio demoleus Linnaeus, 1758 (Lepidoptera: Papilionidae) is an Indo-Australian species originally distributed from the Arabian Peninsula in the west through tropical Asia to Okinawa in the east, and mainland Southeast Asia in the south, occupying several isolated territories. This species also has been recorded in Australia and southern Papua New Guinea. As far as it is known, different populations of the species are well differentiated in DNA structure, morphology, and life cycle [Zakharov et al., 2004; Smith,Vane-Wright, 2008]. At the west $P$. demoleus extends from Iran into Iraq and around the Persian Gulf, following the cultivation of Citrus [Larsen, 1977, 1984; Nazari, 2003] and eastern Arabia from Oman through UAE to Qatar, Bahrain and Kuwait [Walker, Pittaway, 1987; Al-Houty, 2000]. In the New world, it was introduced to the Caribbean where it was first reported in 2004 from the Dominican Republic [Guerrero et al., 2004] and in 2006 from Puerto Rico [Homziak, Homziak, 2006]. The first record of the Lime Swallow- tail in Europe in Portugal, Algarve, in 2012 by D. Morgun and M. Wiemers [2012].

The first observation of $P$. demoleus for Turkey was by Ahmet Koçak [Koçak et al., 2006], who discovered it at Nusaybin (Nisibin), South East Turkey, which faces the Syrian border city of Al Qāmishlī; on the basis of the proximity of Nusaybin to the Syrian border, Koçak reasonably decided that $P$. demoleus should also be added to the Syrian faunistic list. The first official record of $P$. demoleus for Syria was by D. Benyamini [Benyamini et al., 2007] from Al Qaryatayn west of Palmyra in 2003. Finally, O. Başbay summarizes recent reports of the extensive spread of Papilio demoleus in south-eastern Turkey and in regions adjacent to the north-eastern Mediterranean [Başbay et al., 2020], they confirmed the presence of $P$. demoleus in the Latakia Mountains of western Syria, with numerous later observations of the butterfly and its early stages in Citrus groves along the Mediterranean coast of Syria.

\section{Materials and methods}

The two specimens of Papilio demoleus were collected from the Aleppo city (Fig. 1) from 5-10.07.2019 from the point $36.220777^{\circ} \mathrm{N}, 37.158261^{\circ} \mathrm{E}$, where located an abandoned garden of Citrus aurantium tree (Fig. 2); and the temperature was $37{ }^{\circ} \mathrm{C} / 19{ }^{\circ} \mathrm{C}$. Both specimens were males (Fig. 3). Other specimens were observed visiting the citrus trees every morning at the same time (8:30-9:00 am) until the end of October.

\section{Discussion}

Recording of the arrival of $P$. demoleus to Aleppo is important, because it shows further expansion westwards and it actually appeared for the first time in the Levant less than $100 \mathrm{kms}$ from the East Mediterranean coast. Being well-known migrants, a large-scale movement of this species supposed to be achieved from AlQaryatayn since 2003 (the first observation in Syria) to 

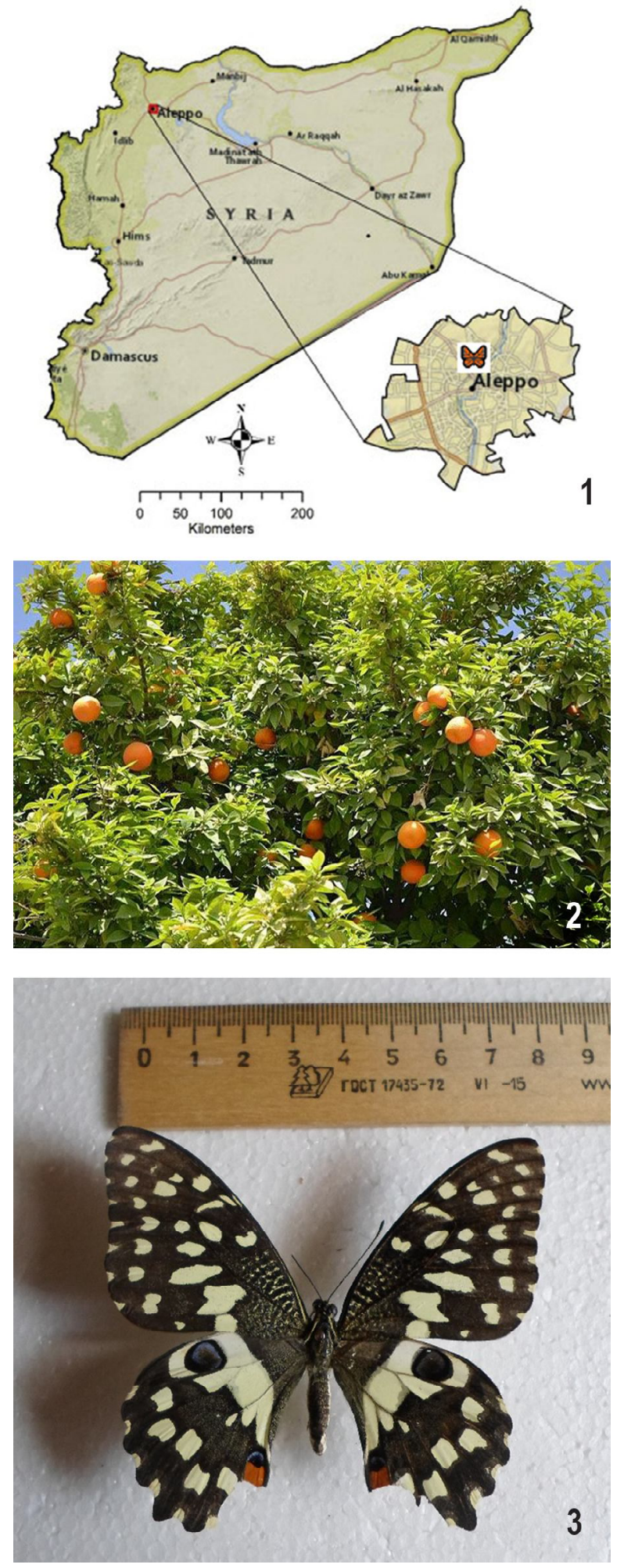

Figs 1-3. P. demoleus from Aleppo, West Syrian Levant. 1 map location, 2 - the host plant tree Citrus aurantium, 3 P. demoleus recorded from Aleppo.

Pис. 1-3. P. demoleus из Амеппо, Западносирийский Аевант. 1 - место сбора, 2 - кормовое растение Citrus aurantium, 3 - P. demoleus из Алеппо.

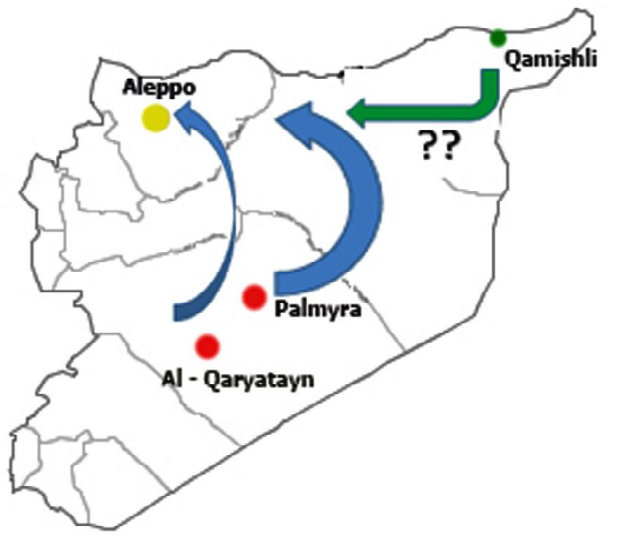

Fig. 4. P. demoleus supposed migration directions in Syria. Рис. 4. Предполагаемые направления миграции P. demoleus в Сирии.

the Aleppo region (Fig. 4). The real duration period of this migration, stopping points in various regions and being the seasonal movement of these species is a regular component of their life history matters that are still arguable. In addition, it is not clear if the migration of this species to the west is reversible in the cold seasons.

However, the only explanation for the westward expansion of the species is the favorable warm climate, due to ongoing climate changing process in the area. This species distribution to the west must consider as an indicator of climate changing during last two decades.

\section{References}

Al-Houty W. 2000. Some Lepidoptera recorded from Kuwait // Nachrichten des Entomologischen Vereins Apollo. Vol.21. No.2. P.109-111.

Başbay O., Salimeh M., John E. 2020. Preliminary note on the range expansion of Papilio demoleus (Lepidoptera: Papilionidae) in south-eastern Turkey, and on the first documented arrival of this invasive species at the Mediterranean coast of Syria // Phegea. Vol.48. No.1. P.20-21.

Benyamini D., Bruschini C., Serra G., John E. 2007. First confirmed records of Papilio demoleus (Linnaeus 1758) in Syria, with comments on the species' appearance in Turkey and the Dominican Republic // News of the Israeli Lepidopterists Society. Vol.24. No.2. P.4-10.

Guerrero K.A., Veloz D., Boyce S.L., Farrell B.D. 2004. First New World Documentation of an Old-World citrus pest, the lime swallowtail Papilio demoleus (Lepidoptera: Papilionidae) in the Dominican Republic (Hispaniola) // American Entomologist. Vol.50. P.227-229.

Homziak N., Homziak J. 2006. First occurrence of the lime swallowtail, Papilio demoleus, an Old World citrus pest, in Puerto Rico // Florida Entomologist. Vol.89. No.4. P.485488.

Koçak A.Ö., Kemal M., Akdeniz D. 2006. A new genus and species to the Lepidoptera fauna of Turkey and Syria (Papilionidae) // Miscellaneous Papers Centre for Entomological Studies Ankara. Vol.97. P.1-6.

Larsen T.B. 1977. Extension récente en Iraq de 1'aire de Papilio demoleus Linné // Entomops. Vol.42. P.37-38.

Larsen T.B. 1984. The zoogeographical composition and distribution of the Arabian butterflies (Lepidoptera; 
Rhopalocera) // Journal of Biogeography. Vol.11. P.119158

Morgun D.M., Wiemers M. 2012. First record of the Lime Swallowtail Papilio demoleus Linnaeus, 1758 (Lepidoptera, Papilionidae) in Europe // Journal of Research on the Lepidoptera. Vol.45. P.85-89.

Nazari V. 2003. Butterflies of Iran. Dayereh-Sabz, Iran. 568p.

Smith C.R., Vane-Wright R.I. 2008. Classification, nomenclature and identification of lime swallowtail butterflies: a post- cladistic analysis (Lepidoptera: Papilionidae) // Systematics and Biodiversity. Vol.6. P.175-203.

Walker D.H., Pittaway A.R. 1987. Insects of Eastern Arabia. Macmillan Publishers, London. 175 p.

Zakharov E.V, Smith C.R., Lees D.C., Cameron A., VaneWright, R.I., Sperling F.A.H. 2004. Independent gene phylogenies and morphology demonstrate a Malagasy origin for a wide-ranging group of Swallowtail butterflies // Evolution. Vol.58. P.2763-2782.

Поступила в редакцию 19.3.2020 